\title{
Environmental management maturity of local and multinational high-technology corporations located in Brazil: the role of business internationalization in pollution prevention
}

\author{
Giovanna Maiallea , Ana Beatriz Lopes de Sousa Jabbour ${ }^{\mathrm{a} *}$, Ariana Fernandes Arantes ${ }^{\mathrm{a}}$, \\ Charbel José Chiappetta Jabbour \\ aUniversidade Estadual Paulista, Bauru, SP, Brazil \\ *abjabbour@feb.unesp.br
}

\begin{abstract}
This paper identifies and characterizes the environmental maturity level of local and multinational high-technology corporations located in Brazil. This characterization is achieved by discussing the adoption of environmental management practices and considering aspects of the productive process stage. An eight-case study was conducted through data triangulation using interviews with employees in diverse organizational areas, direct observations and secondary data. The results indicate the differences in environmental positioning among the studied corporations with a predominance of preventive practices, i.e., an emphasis on eco-efficiency and compliance with legislation. It was also noted that environmental concerns in the corporations are related to internationalization and, in some cases, to the pressure exerted by corporations that represent the brand of the products produced in Brazil. Moreover, the adoption of environmental practices based on the productive process stage supported the environmental maturity classifications of the studied companies.
\end{abstract}

Keywords

Maturity stages. Environmental management. High-technology sector. Brazil.

\section{Introduction}

Brazil is one of the countries that has been receiving increasingly more international attention. In addition to being part of BRIC (Brazil, Russia, India and China) and being considered one of the ten largest world economies, Brazil has abundant natural resources represented by the Amazon forest, for example. In addition, the Brazilian Government has been devoting increasingly more attention to the environmental problems resulting from the economic growth observed over the last decade, when millions of Brazilians rose above the absolute poverty line and when the country began a more intense struggle against the deforestation of natural areas and the pollution of large cities (Jabbour et al., 2012). One of the primary advances in environmental management in Brazil was the release of the New National Policy on Solid Waste, which has required States, Municipalities and Corporations to have plans for the recovery, reuse and recycling of the resources that they use since 2010 (Jabbour et al., 2014). These contexts attempt to increase the level of environmental management maturity of corporations located in Brazil through more advanced environmental management practices.

Organisational environmental management is defined by Jabbour et al. (2009b) as the set of practices inserted into the organisational context that modifies the directives, policies and administrative practices to include the ecological/environmental variable as part of a corporation's objectives. Environmental management may be incorporated at different intensity levels in corporations, thus originating the concept of environmental management maturity (Jabbour et al., 2009a). 
The analysis of corporations' environmental maturity levels is a more theoretical than practical field (Hunt \& Auster, 1990; Berry \& Rondinelli, 1998; Barbieri, 2004; Jabbour \& Santos, 2006). In general, those articles propose or systematise ways to classify companies in environmental maturity levels based on organisational aspects such as commitment of people and resources and development of organisational programmes for environmental management. However, there are empirical studies that deal with the environmental maturity theme. For example, Vastag et al. (1996) found that technological change, better emissions control and monitoring of public opinion move an organisation from the reactive to the preventive stage. Park \& Ahn (2012) considered four factors to analyse corporations' environmental maturity levels. These were the degree to which the programme reduces environmental risk, the commitment of the organisation, programme design and involvement with stakeholders. For Ormazabal et al. (2013), the maturity stage is associated with a number of practices, i.e., key actions that at least several of the companies undertook as part of progressing through the different maturity stages. In a recent study, Ormazabal \& Sarriegi (2014) conducted a survey of Spanish and Italian companies in order to identify factors that characterise the environmental management stage. Those are legislation, training, formalisation, process efficiency and savings, green image, green products and processes, and communication factors. And Huang et al. (2014) considered only the proactive stage of environmental management in their research, and that stage is identified from the analysis of product-focussed pollution prevention, process-focussed pollution prevention and environmental management activities.

Therefore, in principle, there is no unanimity as to the criteria used to classify companies in environmental maturity levels. The unanimity is that there are evolutionary stages, which are important to understand organisational greening, and the adoption of environmental practices is an approach for the classification process.

According to Stevens et al. (2012), there is a need for research to encompass the requirements of differing firms, and their wish to achieve different outcomes beyond simple compliance to an environmental management system has mostly been neglected, thus generating a gap in knowledge of the inclusion of ecological aspects in corporations. It is known that, of all the corporation's components, the production sector is one of the most relevant, as it directly generates pollution and uses natural resources (González-Benito \& González-Benito, 2006). However, some authors we have cited, for example, did not consider aspects of the productive process stage (input-transformation-output) in order to classify the maturity of environmental management. These might be useful and interesting to further analyse the evolution of environmental management more clearly with respect to actions (practices) and the requirements, complementing the current theme of the research stage and responding to a gap identified in the literature.

In this manner, the objective of this research is to identify and characterise the environmental maturity levels of high-technology corporations located in Brazil and identify variables that may influence this process. This country was also chosen because there are relatively few studies on environmental management in Brazilian corporations in comparison with the volume of research on environmental topics in other emergent countries, such as China (Zhu et al., 2012) and India (Muduli et al., 2013).

A multiple case study was performed on eight computer and informatics components manufacture/assembly high-technology corporations. This sector was chosen because of the short life cycles of its products, its economical importance to the country, and the presence of harmful chemical substances in its products' components. In addition, this sector is being directly affected by the directives of the New National Policy on Solid Waste in Brazil.

The article is structured as follows: 1t begins with a literature review on environmental management maturity levels and environmental practices. It then exposes the materials and methods used in the research, and after, in section 4, it shows the results, which are discussed in section 5. It ends with the conclusion resulting from the study in section 6 .

\section{Literature review}

Environmental management maturity levels may be understood as ways of describing the degree to which environmental concerns are integrated into corporate policy and strategy (Kolk \& Mauser, 2002). Certain characteristics permit the classification of corporations at different levels of environmental management maturity. These levels aid corporations in identifying their environmental baseline and establishing strategies to reach the desired environmental management results (Park \& Ahn, 2012).

To Jabbour (2010), characteristics of different environmental maturity levels may coexist within the same corporation; i.e., maturity levels may be non-linear but cumulative. In addition, corporations may be classified as being located at the frontiers between environmental maturity levels (Park \& Ahn, 2012).

According to Jabbour \& Santos (2006), there are three levels of environmental management maturity: 
(1) functional specialisation, (2) internal integration and (3) external integration.

The functional specialisation level represents the institutionalisation of environmental activities in a punctual manner (Corazza, 2003), as with pollution control at the process's output without modification of production and the product's structures (Barbieri, 2004). This level constitutes a reactive approach (Donaire, 1994) used only to avoid complications related to legislation. Environmental management is not considered a business opportunity but a hindrance to reaching the corporation's goals (Jabbour et al., 2009a). Table 1 presents the characteristics of the Functional Specialisation of Environmental Management level.

The internal integration level, marked by the creation of an environmental department, focuses on preventing pollution and on eco-efficiency and has a strong interface with the production area (Donaire, 1994); however, environmental management is still not considered a strategic factor that can result in potential profit for the corporation (Table 2).

Finally, the external integration level represents the maximum environmental maturity in a corporation, consisting of a strong incorporation of environmental themes into the corporation's strategy (Donaire, 1994). The environmental department becomes more prestigious, focuses on a green market and generates competitive advantages. A diagnosis of all of the corporation's areas becomes necessary, including the integration of the supply chain containing the providers (Jabbour \& Santos, 2006). At this environmental maturity level, employees are largely involved in the corporation's environmental management (Table 3).

Table 1. Systematisation of the characteristics related to the Functional Specialisation of Environmental Management (Reactive).

\begin{tabular}{lc}
\multicolumn{1}{c}{ Related characteristics } & Authors \\
\hline Reactive approach, with environmental control of the output. & Donaire (1994) \\
\hline Adaptation to market's demands, with control of the output. & Maimon (1994) \\
\hline Use of environmental regulation standards. & Sanches (2000) \\
\hline Compliance with legislation and corrective actions (end-of-pipe). & Barbieri (2004) \\
\hline Waste control. & Rohrich \& Cunha (2004) \\
\hline $\begin{array}{l}\text { Does not consider environmental management to be important; resources are only released when } \\
\text { necessary. Partial involvement with other departments and with high administration. }\end{array}$ & Hunt \& Auster (1990) \\
\hline $\begin{array}{l}\text { Environmental management still does not have strategic values; however, changes are implemented as } \\
\text { required by legislation. }\end{array}$ & Azzone \& Bertelè (1994) \\
\hline Inserts environmental practices as necessary because of external pressure, aiming only to comply. & Post \& Altman (1994) \\
\hline Compliance with norms and legislations (cost mode). & Berry \& Rondinelli (1998) \\
\hline
\end{tabular}

Table 2. Systematisation of the characteristics related to Internal Integration level (Preventive).

\begin{tabular}{lc}
\hline \multicolumn{1}{c}{ Related characteristics } & Authors \\
\hline Integration of environmental control into practices and processes. & Donaire (1994) \\
\hline Creation of the environmental management department and its initial actions. & Corazza (2003) \\
\hline Pollution prevention: Use of cleaner technology and the substitution of inputs. & Barbieri (2004) \\
\hline Pollution prevention with specialists in the area. & Rohrich \& Cunha (2004) \\
\hline Minimal but fixed budget. Moderate engagement of high administration. & Azzone \& Bertelè (1990) \\
\hline $\begin{array}{l}\text { The corporation anticipates the legislation's requirements for processes and technologies. Insertion of } \\
\text { the environmental management department. }\end{array}$ & Post \& Altman (1994) \\
\hline $\begin{array}{l}\text { The environmental values coexist with the other corporate values. The environmental management } \\
\text { department is crucial for reports, communications and evaluation. }\end{array}$ & \\
\hline
\end{tabular}

Table 3. Systematisation of the practices related to the External Integration level (Proactive).

\begin{tabular}{|c|c|}
\hline Related practices & Authors \\
\hline $\begin{array}{l}\text { Integration of environmental control into general management. Environmental excellence becomes } \\
\text { necessary for the company in the search for a green market. }\end{array}$ & Donaire (1994) \\
\hline Proactive behaviour integrating the environmental function into the corporation's strategic planning. & Maimon (1994) \\
\hline Incorporation of environmental values as an opportunity for the corporation. & Sanches (2000) \\
\hline Integration of environmental policy into all of the corporation's areas. & Corazza (2003) \\
\hline Environmental impact assessment, modifications in processes and products. & Rohrich \& Cunha (2004) \\
\hline $\begin{array}{l}\text { Environmental management is a priority. High administration and all of the departments involved. } \\
\text { Consistent internal and external reports. Significant involvement in product design, production line, public } \\
\text { relations and the juridical department. }\end{array}$ & Hunt \& Auster (1990) \\
\hline $\begin{array}{l}\text { Examines the opportunity for the environmental differentiation of products or processes searching for } \\
\text { consumers that are interested in a "green" product. }\end{array}$ & Azzone \& Bertelè (1994) \\
\hline $\begin{array}{l}\text { Environmental development goals are rooted throughout the entire company, are clear and are considered } \\
\text { an opportunity for development and differentiation. }\end{array}$ & Post \& Altman (1994) \\
\hline $\begin{array}{l}\text { Minimisation of waste production and the prevention of pollution, modifications to products and in } \\
\text { processes (sustainable business mode). }\end{array}$ & Berry \& Rondinelli (1998) \\
\hline
\end{tabular}


To appropriately analyse the environmental maturity level of a given corporation, the following variables must be considered (based on information above and on Vastag et al., 1996):

- The position of environmental concerns within the organisational structure;

- The actual focus (whether reactive, preventive or strategic) of environmental actions;

- The interaction of environmental management with other areas of the corporation;

- The support provided by high administration to environmental concerns.

To progress from one environmental management maturity level to the next, corporations must use so-called environmental management practices (González-Benito \& González-Benito, 2006), the following of which may be highlighted (based on Garrod \& Chadwick, 1996; liu et al., 2010):

- Ecodesign: Considers the materials and methods that will cause the least environmental impact when conceiving the product (Sarkis, 1998). The objective is the creation and development of products through the optimisation of available resources, environmental preservation and the improvement of the quality of products;

- Life-cycle assessment: This tool is one of the most efficient for measuring the environmental impacts of a production process (Sarkis \& Rasheed, 1995). This type of evaluation considers aspects from the preparation of raw material inputs, the water and energy used and the emission of pollutants during the process to the end of the product's life cycle and its disposal (Sarkis, 1998);

- ISO 14001: The ISO 14001 standard was created in 1996 to aid companies in establishing a certifiable Environmental Management System (EMS) (Seiffert, 2009);

- 3 Rs: Reduce, Reuse and Recycle the resources, in this priority order;

- Environmental Supply Chain Management: The environmental focus on the management of the supply chain is an opportunity to minimise the environmental impacts, from before the raw materials entrance into the corporation to its disposal and recovery (Nascimento et al., 2008);

- Cleaner Production (CP): Implanting CP means avoiding or reducing the production of pollutants through strict control of the production process, i.e., efficiently using non-renewable resources, conserving renewable resources and not surpassing the environment's waste assimilation capacity; i.e., if the production of pollutants is inevitable, they must be reintegrated into the process (Barbieri, 2004);

- Pollution Control Practices: These practices constitute a remediation or end-of-process (end-of-pipe) action such as the use of effluent treatment stations, filters or incinerators (Barbieri, 2004).

Regarding the Brazilian studies concerning the environmental maturity levels theme, recently, this issue has been approached to analyse the interrelationships between that and dimensions of human resources (Jabbour et al., 2009b; 2013), adoption of green supply chain management practices (Jabbour, 2014) and improved environmental and economic performance (Sehnem \& Rossetto, 2014).

Therefore, this article tends to advance on the discussion of organisational environmental maturity while adding more evidence regarding how best to identify which environmental maturity level a company is, due to the relationship between the profile of environmental practices with the productive process stage (input-processing-output), and to discuss other variables that might influence the organisational greening.

\section{Materials and methods}

\subsection{Study object}

The justification for the choice of the high-technology sector is that its products have been rapidly becoming obsolete, leading to increased disposal. This equipment contains approximately $60 \%$ of hazardous chemical substances, such as iron, copper, gold, aluminium and other metals, which leads "e-waste" to be classified as presenting high environmental risk (Widmer et al., 2005). The favourable economic development of the high-technology sector, among other sectors of Brazilian industry, must also be considered. When creating the sample of companies, certain characteristics were considered: they had to belong to the same high-technology branch (focusing on computers and informatics components), and they had to allow the development of this research. In total, the operation segments of eight leading companies in Brazil were analysed.

\subsection{Sampling procedures and data analysis}

First, an interview script was elaborated that incorporated the primary concepts of the literature review presented in Section 2. This script was dedicated to characterising the environmental management of the corporations and the adopted environmental practices. 
Table 4 details the data sampling process, which began in 2012 and was developed using data triangulation incorporating interviews, direct observations made at the site and secondary data. The application of the research plan using the corporations' workers also considered posterior contacts so that potential

Table 4. Characterisation of the eight corporations studied and characterisation of the collected data.

\begin{tabular}{|c|c|c|c|}
\hline Corporation & Characterisation & Interview & Secondary data \\
\hline 1 & $\begin{array}{l}\text { Multinational assembler of printers, projectors } \\
\text { and derivatives } \\
\text { lts branch in Brazil is of medium size, and it } \\
\text { assembles only matrix and fiscal printers, with } \\
\text { the other products being imported from the } \\
\text { headquarters }\end{array}$ & $\begin{array}{l}\text { - Environmental } \\
\text { coordinator } \\
\text { - Manufacturing engineer }\end{array}$ & $\begin{array}{l}\text { - PowerPoint presentation on the } \\
\text { sustainability programs and the } \\
\text { environmental improvement goals } \\
\text { - Internal flyer presenting the } \\
\text { corporation's environmental } \\
\text { management policy } \\
\text { - Data obtained from the corporation's } \\
\text { and the corporation headquarters' } \\
\text { website }\end{array}$ \\
\hline 2 & $\begin{array}{l}\text { National assembler/manufacturer of large size } \\
\text { computers (desktop), notebooks, netbooks, } \\
\text { tablets and other items } \\
\text { Leader in computer fabrication and sales in } \\
\text { Brazil }\end{array}$ & $\begin{array}{l}\text { - Sustainability coordinator } \\
\text { - Quality engineer }\end{array}$ & $\begin{array}{l}\text { - Data available on the lnternet } \\
\text { - Data on environmental projects } \\
\text { - Documents available on the } \\
\text { corporation's website }\end{array}$ \\
\hline 3 & $\begin{array}{l}\text { Multinational assembler of computers } \\
\text { (desktop) and notebooks. This organisation's } \\
\text { entrance into the Brazilian market is recent } \\
\text { The organisation's strategy is to outsource the } \\
\text { entire production process by contracting and } \\
\text { managing assembler corporations }\end{array}$ & $\begin{array}{l}\text { - Hygiene and work safety } \\
\text { engineer } \\
\text { - Project manager }\end{array}$ & $\begin{array}{l}\text { - Data and information available on the } \\
\text { corporation's and the headquarters' } \\
\text { website }\end{array}$ \\
\hline 4 & $\begin{array}{l}\text { National large size assembler/manufacturer } \\
\text { of desktops, notebooks, netbooks, bank } \\
\text { automation and technological services } \\
\text { Exports and has subsidiary companies abroad }\end{array}$ & - Environmental analyst & $\begin{array}{l}\text { - Data on the sustainability program, } \\
\text { the environmental policy, a } \\
\text { manual for the conscious user and } \\
\text { information on the legal requirements } \\
\text { followed by the corporation available } \\
\text { on the corporation's website }\end{array}$ \\
\hline 5 & $\begin{array}{l}\text { A contracted large size multinational } \\
\text { corporation that assembles printers, } \\
\text { notebooks, computers, tables, credit card } \\
\text { terminals, cell phones and other items for } \\
\text { renowned corporations }\end{array}$ & $\begin{array}{l}\text { - Environmental supervisor } \\
\text { - Project coordinator } \\
\text { - Systems analyst }\end{array}$ & $\begin{array}{l}\text { - Data and information available on the } \\
\text { Internet, PowerPoint presentation on } \\
\text { environmental projects, programs and } \\
\text { results developed by the corporation } \\
\text { with its suppliers and customers } \\
\text { - Internal flyer on the corporation's } \\
\text { environmental policy, mission, } \\
\text { objectives and goals } \\
\text { - Data available on the corporation's } \\
\text { website }\end{array}$ \\
\hline 6 & $\begin{array}{l}\text { A contracted large size multinational } \\
\text { corporation that assembles printers, cartridges, } \\
\text { toners, document readers and credit card } \\
\text { terminals, among other items, for renowned } \\
\text { (customer) corporations }\end{array}$ & $\begin{array}{l}\text { - Quality Assistant } \\
\text { - Quality Analyst } \\
\text { - Quality Auxiliary }\end{array}$ & $\begin{array}{l}\text { - Documents available on the } \\
\text { corporation's website } \\
\text { - Flyer regarding the environmental } \\
\text { management week offered to the } \\
\text { employees } \\
\text { - Flyer on the environmental policy, } \\
\text { mission and goals }\end{array}$ \\
\hline 7 & $\begin{array}{l}\text { Multinational large size assembler/ } \\
\text { manufacturer of desktop, servers, notebooks, } \\
\text { netbooks, ultrabooks and all-in-ones }\end{array}$ & $\begin{array}{l}\text { - Project and social and } \\
\text { environmental supply } \\
\text { chain responsibility } \\
\text { coordinator }\end{array}$ & $\begin{array}{l}\text { - Information and documents } \\
\text { available on the corporation's } \\
\text { website regarding sustainability, } \\
\text { environmental policy, mission and } \\
\text { goals } \\
\text { - Data supplied by intranet and } \\
\text { PowerPoint documents on internal } \\
\text { environmental actions accomplished } \\
\text { with the suppliers and customers } \\
\text { - Flyer on the corporation's } \\
\text { environmental policy, mission and } \\
\text { goal }\end{array}$ \\
\hline 8 & $\begin{array}{l}\text { A contracted large size multinational } \\
\text { corporation that assembles notebooks, } \\
\text { netbooks, desktops and tablets, among other } \\
\text { items, for renowned (customer) corporations. } \\
\text { This organisation is the largest electronic } \\
\text { manufacturer contracted corporation }\end{array}$ & $\begin{array}{l}\text { - Quality analyst } \\
\text { - Quality engineer }\end{array}$ & $\begin{array}{l}\text { - Information on the environmental } \\
\text { management and policy available on } \\
\text { the headquarters' website } \\
\text { - Flyer on the corporation's } \\
\text { environmental policy and goals }\end{array}$ \\
\hline
\end{tabular}


uncertainties could be clarified. To provide a full understanding of reality, at least two employees were interviewed when possible. Direct observations were made during the visits to the corporations, both on the production line and in the areas dedicated to waste sorting when possible. Diverse secondary data were collected as well.

The studied companies can be classified as follows:

- Brazilian local organisations (National product development and manufacturing) (Cases 2 and 4); or

- Multinational organisations with an industrial unit/subsidiary operating in Brazil (belongs to the same corporate group, with a local production following product development and manufacturing guidelines suggest by the Headquarters) (Cases 1, 3 and 7); or

- Multinational organisations with an industrial unit/subsidiary operating in Brazil (this organisation is contracted by other companies that detains international and well-established brands; thus, this type of organization produces accordingly to an agreement and following the organisation-customer requirements - the brand owner) (Cases 5, 6 and 8).

The results were analysed using data systematisation and tabulation for the posterior comparison of these results and the concepts presented in Section 2.

\section{Results}

\subsection{Characterisation of the corporations' environmental management maturity}

Table 5 presents the primary results regarding the environmental management profile of the studied companies, considering the criterions selected during the literature review: (a) how environmental management is inserted into the corporation's organisational structure, (b) the focus of the corporation's efforts towards environmental management, (c) the interaction between environmental management and other functional areas and (d) support offered by high administration.

In general, environmental management activities are linked not to a separate Department but to other departments, with a predominance of Quality (Corporations 2, 4 and 6) and Work Safety (Corporations 3, 7 and 8) areas. The exceptions are Corporation 1, which has a single employee (Environmental Coordinator) who responds directly to the board, and Corporation 5, which has a department dedicated to the environmental facet and an advanced Research and Development (R\&D) centre with emphasis on more sustainable innovations.
As to the focus of environmental management, all of the studied corporations seek to comply with legal environmental requirements and with eco-efficiency principles (the reduction of energy and water consumption and the reduction of waste production) in their processes. Corporations 2, 5 and 7 have been proposing changes in the product development process to incorporate alternative and renewable materials. For example, Corporation 2 has been studying the recycling of the plastic used in laptops, and Corporation 5 has been effectively implementing ecodesign in partnership with its customers and suppliers.

The integration of the environmental management area with the other areas of the organisation occurs in different manners in the studied corporations. With regard to the Logistics area, environmental management creates performance indicators for the logistics providers (Corporation 1), such as control of the $\mathrm{CO} 2$ emission of the vehicle fleet (Corporation 7). In its turn, Logistics aids environmental management through the use of reverse logistics for packages and after-consumption (Corporations 1, 4, 6 and 7). Environmental management provides information on the environmental performance of products so that the Marketing area may disclose this information to customers (green marketing) (Corporations 1 and 4). The Production area interacts with the environmental management area through the reduction of the environmental impacts of its productive processes (Corporations 5, 6 and 7). The Purchase area collaborates with environmental management by selecting and auditing suppliers so that they can provide environmentally adequate components (Corporations 4, 5 and 8). The Human Resources area supports environmental management by providing environmental training for employees (Corporations 6 and 8). The Quality area tends to share human and physical resources with the environmental management area (Corporations 2, 4, 6 and 8).

Some considerations must also be made with regard to internal environmental management and support from high administration. The Lead-Free (lead elimination) process has been adopted by nearly all of the studied companies and is part of RoHS Compliance, a European directive that prohibits the use of dangerous substances. Although it is neither a law nor a Brazilian requirement, the corporations opt to follow these directives because of exportation (Corporation 4), headquarters' requirements (Corporations 1, 5, 6, 7 and 8) or a corporate philosophy of adequacy with regard to cleaner production (Corporation 2).

The local actions of Corporations 1, 3 and 7, which are brand-owning multinational corporations, are influenced by the headquarters' environmental goals. 
In other words, the headquarters of these corporations adopt environmental management practices that are followed by the units located in Brazil.
Corporations that outsource their production process to other corporations (Corporations 3 and 7) must constantly perform environmental evaluations

Table 5. Characterisation of the studied corporations' environmental management.

\begin{tabular}{|c|c|c|c|c|}
\hline Corporation & Organisational structure & $\begin{array}{c}\text { Focus of environmental } \\
\text { management }\end{array}$ & $\begin{array}{l}\text { Interaction with } \\
\text { functional areas }\end{array}$ & Support offered by high administration \\
\hline 1 & $\begin{array}{l}\text { - A single environmental } \\
\text { coordinator position that } \\
\text { responds directly to the } \\
\text { director of the branch }\end{array}$ & $\begin{array}{l}\text { - Legislation } \\
\text { - Eco-efficiency }\end{array}$ & $\begin{array}{l}\text { - Commercial } \\
\text { - Logistics } \\
\text { - Technical assistance }\end{array}$ & $\begin{array}{l}\text { - Support from high administration } \\
\text { - Adopts Lead-Free processes and follows } \\
\text { the RoHS Compliance directives } \\
\text { - Follows the headquarters' } \\
\text { environmental goal directives }\end{array}$ \\
\hline 2 & $\begin{array}{l}\text { Department of quality } \\
\text { and environment }\end{array}$ & $\begin{array}{l}\text { - Legislation } \\
\text { - Eco-efficiency } \\
\text { - Support in the } \\
\text { development of } \\
\text { products with smaller } \\
\text { environmental impacts }\end{array}$ & - RetD & $\begin{array}{l}\text { - Support from high administration } \\
\text { - Support from middle administration } \\
\text { - Adopts Lead-Free processes and follows } \\
\text { the RoHS Compliance directives } \\
\text { - Sustainable area inside the facility with } \\
\text { the objective of practicing the three Rs }\end{array}$ \\
\hline 3 & $\begin{array}{l}\text { - Department of hygiene } \\
\text { and work safety }\end{array}$ & $\begin{array}{l}\text { - Legislation } \\
\text { - Eco-efficiency }\end{array}$ & $\begin{array}{l}\text { No areas, as the Brazilian } \\
\text { branch does not have a } \\
\text { production unit }\end{array}$ & $\begin{array}{l}\text { - Support from high administration } \\
\text { - Audits conducted in the contracted } \\
\text { corporations to verify environmental } \\
\text { requirements } \\
\text { - Follows the headquarters' } \\
\text { environmental goal directives }\end{array}$ \\
\hline 4 & $\begin{array}{l}\text { - Department of quality } \\
\text { and environment } \\
\text { - Sustainability executive } \\
\text { management }\end{array}$ & $\begin{array}{l}\text { - Legislation } \\
\text { - Eco-efficiency }\end{array}$ & $\begin{array}{l}\text { - Logistics } \\
\text { - Marketing } \\
\text { - Purchase }\end{array}$ & $\begin{array}{l}\text { - Support from high administration } \\
\text { - Support from middle administration } \\
\text { - Adopts Lead-Free processes and follows } \\
\text { the RoHS Compliance directives } \\
\text { - Recycling Centre inside the facility with } \\
\text { the objective of practicing the three Rs }\end{array}$ \\
\hline 5 & $\begin{array}{l}\text { - A separate department } \\
\text { - Specialised centre for } \\
\text { environmental RED for } \\
\text { customers }\end{array}$ & $\begin{array}{l}\text { - Legislation } \\
\text { - Eco-efficiency } \\
\text { - Development of } \\
\text { products with smaller } \\
\text { environmental impacts } \\
\text { - Process modifications } \\
\text { for smaller } \\
\text { environmental impact }\end{array}$ & $\begin{array}{l}\text { - } \text { Marketing } \\
\text { - Production and } \\
\text { Engineering } \\
\text { - Purchase } \\
\text { - R\&D }\end{array}$ & $\begin{array}{l}\text { - Support from high administration } \\
\text { - Support from middle administration } \\
\text { - Adopts Lead-Free processes and follows } \\
\text { the RoHS Compliance directives } \\
\text { - Uses fiscal incentives to conduct } \\
\text { research on environmental innovation } \\
\text { and technology } \\
\text { - Energy Star certificate (energetic } \\
\text { efficiency of the device) }\end{array}$ \\
\hline 6 & - Department of Quality & $\begin{array}{l}\text { - Legislation } \\
\text { - Eco-efficiency }\end{array}$ & $\begin{array}{l}\text { - Logistics } \\
\text { - Production and } \\
\text { Engineering } \\
\text { - Human Resources }\end{array}$ & $\begin{array}{l}\text { - Support from high administration } \\
\text { - Adopts Lead-Free processes and follows } \\
\text { the RoHS Compliance directives }\end{array}$ \\
\hline 7 & $\begin{array}{l}\text { - Integrated departments: } \\
\text { SER (Social and } \\
\text { Environmental } \\
\text { Responsibility) and EHS } \\
\text { (Environment, Health } \\
\text { and Safety) }\end{array}$ & $\begin{array}{l}\text { - Legislation } \\
\text { - Eco-efficiency } \\
\text { - Development of } \\
\text { products with smaller } \\
\text { environmental impacts }\end{array}$ & $\begin{array}{l}\text { - Production and } \\
\text { Engineering } \\
\text { - Purchase } \\
\text { - Logistics }\end{array}$ & $\begin{array}{l}\text { - Support from high administration } \\
\text { - Support from middle administration } \\
\text { - Adopts Lead-Free processes and follows } \\
\text { the RoHS Compliance directives } \\
\text { - Energy Star Certificate } \\
\text { - Audits conducted in the contracted } \\
\text { corporations to verify the environmental } \\
\text { requirements } \\
\text { - Follows the headquarters' } \\
\text { environmental goal directives }\end{array}$ \\
\hline 8 & $\begin{array}{l}\text { - Integrated departments: } \\
\text { SER (Social and } \\
\text { Environmental } \\
\text { Responsibility), EHS } \\
\text { (Environment, Health } \\
\text { and Safety) and Human } \\
\text { Resources }\end{array}$ & $\begin{array}{l}\text { - Legislation } \\
\text { - Eco-efficiency }\end{array}$ & $\begin{array}{l}\text { - Quality } \\
\text { - Purchase } \\
\text { - Human Resources }\end{array}$ & $\begin{array}{l}\text { - Support from high administration } \\
\text { - Adopts Lead-Free processes and follows } \\
\text { the RoHS Compliance directives } \\
\text { - } 1 \mathrm{SO} 14064\left(\mathrm{CO}_{2} \text { emission directives) }\right. \\
\text { - Follows the headquarters' } \\
\text { environmental goal directives }\end{array}$ \\
\hline
\end{tabular}


in the corporations that they hire. Corporations 5 and 8 , which produce using contracts and orders, follow the environmental management requisitions solicited by their large customers.

\subsection{Characterisation of the environmental management practices}

The environmental practices adopted by the studied corporations were organised according to productive process stage (Input-Transformation-Output), according to Table 6 .

For a better understanding of Table 6 , it is important to emphasise that the practices are gaining values as they move from the final stage towards the initial state of the transformation process, i.e., from output to input and from an end-of-pipe approach towards a more strategic approach to the product life cycle. The adoption of practices tends to occur in a gradual manner, as the simplest and most commonly adopted practices are those related to the process's end (output), followed by those related to the transformation stage. However, when more environmental strategy is present, the practices used during the input-stage are initiated. These practices require a larger investment in environmental management, both internal and external to the company, including suppliers.

All of the studied corporations adopt practices at the end of the process (output). The exception is Corporation 3, as it outsources the productions and assembly of its product and therefore does not make use of these practices itself. In general, the corporations use end-of-pipe equipment such as filters or chimneys to avoid atmospheric emissions and/or have a place at the facility (Corporations 2 and 4) in which to separate packages or unusable inputs for correct reuse, recycling or destination. In some cases (Corporations 5 and 7), outsourced corporations were contracted to perform the reverse logistics of post-consummation.

All of the studied corporations presented environmental management actions directed at the transformation stage. All of the corporations are ISO 14001 certified and have internal eco-efficiency goals with regard to water, energy and waste reduction. All (except for Corporation 3) also modified the welding process (lead free) to meet international environmental requirements (RoHS). Some corporations also seek to substitute equipment to increase energetic efficiency (Corporations 4, 5, 7 and 8). Emphasis may be given to Corporation 5 , which has acquired diverse cleaner technology for process modification.

Only three corporations (Corporations 2, 5 and 7) use environmental practices at the beginning of the process. Corporation 2 performs life cycle analysis of the product to map out the stages of plastic package processing. Corporations 5 and 7 are members of the EICC (Electronic Industry Citizenship Coalition), which incorporates environmental directives for the electronic industry. Thus, Corporations 5 and 7 perform life cycle

Table 6. Environmental management practices adopted according to the phases of the transformation process.

\begin{tabular}{|c|c|c|c|}
\hline \multirow{2}{*}{ Corporation } & \multicolumn{3}{|c|}{ Adopted Environmental Management Practices } \\
\hline & lnput & Transformation & Output \\
\hline 1 & & $\begin{array}{l}\text { - ISO } 14001 \\
\text { - CP (Lead free) }\end{array}$ & - Pollution Control of the Outputs \\
\hline 2 & - Life Cycle Analysis & $\begin{array}{l}\text { - ISO } 14001 \\
\text { - CP (Lead free) }\end{array}$ & - Pollution Control of the Outputs \\
\hline 3 & & - ISO 14001 & - Three Rs \\
\hline 4 & & $\begin{array}{l}\text { - } 1 \text { SO } 14001 \\
\text { - CP (Lead free and equipment } \\
\text { substitution) }\end{array}$ & $\begin{array}{l}\text { - Pollution Control of the Outputs } \\
\text { - Three Rs }\end{array}$ \\
\hline 5 & $\begin{array}{l}\text { - Ecodesign } \\
\text { - Life Cycle Analysis (EICC) } \\
\text { - Environmental Management of the } \\
\text { Supply Chain (EICC) }\end{array}$ & $\begin{array}{l}\text { - ISO } 14001 \\
\text { - CP (Lead free, equipment substitution } \\
\text { and process modifications) }\end{array}$ & $\begin{array}{l}\text { - Pollution Control of the Outputs } \\
\text { - Three Rs (outsourced) }\end{array}$ \\
\hline 6 & & $\begin{array}{l}\text { - ISO } 14001 \\
\text { - CP (Lead free) }\end{array}$ & - Pollution Control of the Outputs \\
\hline 7 & $\begin{array}{l}\text { - Life Cycle Analysis (EICC) } \\
\text { - Environmental Management of the } \\
\text { Supply Chain (EICC) }\end{array}$ & $\begin{array}{l}\text { - } 1 \text { SO } 14001 \\
\text { - CP (Lead free and equipment } \\
\text { substitution) }\end{array}$ & $\begin{array}{l}\text { - Pollution Control of the Outputs } \\
\text { - Three Rs (outsourced) }\end{array}$ \\
\hline 8 & & $\begin{array}{l}\text { - } 1 \text { SO } 14001 \\
\text { - CP (Lead free and equipment } \\
\text { substitution) }\end{array}$ & - Pollution Control of the Outputs \\
\hline
\end{tabular}


analysis of the products and involve suppliers in this tracking process. In addition to performing life cycle analysis as part of the environmental management of the supply chain, Corporation 5 adopts ecodesign for its products. As the objective of the present study is to analyse the environmental management maturity of the units located in Brazil, practices such as ecodesign and life cycle analysis performed at the headquarters of the studied corporations (Corporations 1, 3 and 8) were not considered.

\section{Discussion}

Based on the data in Table 5 and Table 6, it is possible to classify the studied corporations in terms of Jabbour \& Santos's (2006) environmental management maturity levels, according to Figure 1.

This study did not identify any corporation as being at the essentially reactive level (functional specialisation). Three cases (Corporations 1, 3 and 6) were classified as experiencing the transition from the Functional Specialisation level to the Internal Integration level. Three cases fit into the Internal Integration level (Corporations 2, 4 and 8). A single case was observed to be at the transition from the preventive to the proactive level (Corporation 7). Finally, a single case presents characteristics of the External Integration level (Corporation 5).

Corporations 1, 3 and 6 were classified as moving towards the intermediate level of environmental management, as the environmental management area has little integration with the other areas of the corporations. In these cases, environmental management essentially focuses on achieving eco-efficiency goals and legal environmental requirements (such as RoHS). As a consequence, environmental management practices with regard to pollution control and CP (e.g., lead free) are adopted (Donaire, 1994). These corporations are multinational and, in the cases of
Corporations 1 and 3, their headquarters appear to have more developed environmental management (they practice ecodesign, life cycle analysis, green purchasing, etc.), but their branches in Brazil only complete the projects that have already been developed at the headquarters. Therefore, the Brazilian branches (Corporations 1 and 3) do not have full environmental management autonomy during the initial stages of the production process. Conversely, Corporation 6, which works only on demand, follows the environmental requirements demanded by the customers (Post \& Altman, 1994).

Corporations 2, 4 and 8 were classified within the preventive level because their environmental management areas are integrating with the other areas of the corporation (Corazza, 2003) and exhibit slightly more participation in product planning, reverse logistics and green purchasing. Two of these corporations provide a site intended for aspects of the separation, reuse and recycling of inputs/products within their facilities. Environmental management still focuses on eco-efficiency and compliance with legal environmental aspects, but these corporations have begun the search for environmental modifications to equipment, and they use the life cycle analysis tool (Barbieri, 2004). The cases in which there is Brazilian capital (Corporations 2 and 4) have been much concerned with aspects of reuse and recycling of their inputs/products, as in 2010, Brazil adopted the New National Policy on Solid Waste which, among other directives, makes the manufacturers responsible for the reverse logistics of their products; thus, these corporations have their own recycling centres.

Corporation 7 was classified as experiencing the transition between the preventive and the proactive levels based on aspects of the interaction of the environmental management area with other areas of the corporation (Corazza, 2003), in addition to the environmental management's consideration of

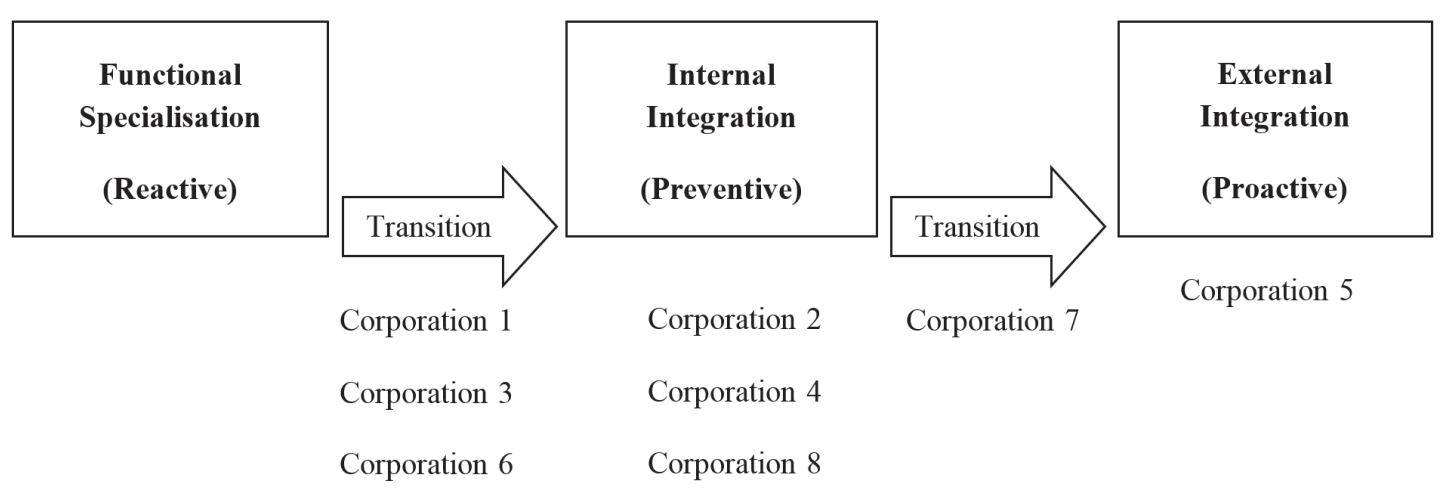

Figure 1. Classification of the studied corporations into the environmental management maturity levels. 
aspects of modifications in product development rather than only end-of-pipe actions and eco-efficiency. As this corporation is a member of the EICC, it incorporates traceability of its suppliers and, thus, performs practices such as life cycle analysis and environmental management of supply chain (Azzone \& Bertelè, 1994). Conversely, this corporation is not at a more advanced environmental maturity level because it is very dependent on its headquarters and does not have full independence in terms of environmental management.

Corporation 5 was considered proactive because it is the only corporation with a department dedicated solely to environmental management in addition to an $R \& D$ centre with an emphasis on sustainability and dedication to its customers' projects (Azzone \& Bertelè, 1994). The environmental management area interacts with the primary functional areas of Corporation 5 and adopts environmental management practices during all of the stages of the transformation process (input-processing-output). This corporation is also the only one to act independently during the product process and the environmental improvement process (Berry \& Rondinelli, 1998; Rohrich \& Cunha, 2004).

Empirical articles that dealt with the subject of the environmental management maturity adopted different criteria to classify companies into maturity levels: changes in processes, products and degree of organisational commitment to environmental management (Vastag et al., 1996; Park \& Ahn, 2012; Ormazabal et al., 2013; Ormazabal \& Sarriegi, 2014; Huang et al., 2014). In general, the adoption of environmental practices reflects the environmental maturity of an organisation. However, a way to better systematise the relationship between the adoption of environmental practices and environmental maturity was not identified. In this article, we adopted the criterion to relate the profile of environmental practice with the phase of the transformation process (input-transformation-output) in order to understand organisational environmental maturity. This criterion proved interesting, especially emphasising that the adoption of environmental practices and the evolution of environmental maturity is a gradual and cumulative process, which begins with the focus shifting from the output to the input.

Another interesting result of this article was determining that aspects of internationalisation tend to affect organisational environmental maturity. Companies 1, 3 and 6 are in lower stages of maturity than the others, even though they are multinational companies. What justifies this is that even though they are subsidiaries of major international companies, those companies operate in Brazil restricted to product assembly (companies 1 and 6) and the management of the supply chain (company 3), following the guidelines of the matrices. In this sense, all of them have little independence to develop environmental programmes and tend to be in a lower maturity stage in the matrices.

Additionally, this article presents a study in the Brazilian context, bringing theoretical and empirical evidence to the theme of the maturity of environmental management, which has been further treated in an incipient way in the national context, and interrelating dimensions of human resource approaches (Jabbour et al., 2009b; 2013), adoption of green supply chain management practices (Jabbour, 2014) and improved environmental and economic performance (Sehnem \& Rossetto, 2014) with organisational environmental maturity.

Therefore, this article complements the discussion of the theme of organisational environmental maturity while adding more evidence with respect to how best to identify which evolutionary stage a company is in, due to relating the profile of environmental practices with the productive process stage (input-transformation-output), and discussing other variables that might influence organisational greening, such as organisational internationalisation.

\section{Conclusions}

This research had the objective of identifying and characterising the environmental maturity levels of eight high-technology companies located in Brazil in order to fill a gap that was found by Stevens et al. (2012), which stated that there is a need for research to encompass the requirements of differing firms and their wish to achieve different outcomes beyond simple compliance to an environmental management system.

A primary conclusion of the present study is that there is a relation between the adoption of environmental management practices and maturity level. It is noted that Corporation 5, with the highest proactivity level, is also the corporation that uses all of the environmental practices considered in this study, including the most important practices at the beginning of the process. Corporations 1, 3 and 6, classified between the reactive and preventive levels, count on only end-of-process practices and legal requirements (RoHS). This logic also applies to intermediate-level corporations (Corporations 2, 4 and 8). It is also evident that these practices are incorporated in a gradual and cumulative manner, beginning with the outputs of the productive process (end-of-pipe) and progressing in reverse towards the adoption of more advanced environmental practices, i.e., towards the inputs of the production system. 
The present study also corroborates the results obtained by Jabbour (2010) and Park \& Ahn (2012), who explain that characteristics of different maturity levels may coexist within the corporation and that environmental maturity is not always linear. Corporations 1, 3, 6 and 7, which were classified as "in transition", are practical examples of this conceptual premise.

It should be emphasised that the branches of multinational corporations (Corporations 1, 3 and 7) attend to environmental goals determined by the headquarters so that their products meet a standard (Epstein \& Roy, 2007). The headquarters are usually at a higher maturity level than the local branch, as the local corporation is responsible only for following the headquarters' directives and is not independent with regard to planning the product, selecting suppliers for critical inputs and changing the production process. As a consequence, these corporations tend to evolve in environmental terms only after the evolution of their headquarters, which depends on the quality of the international time, reflected in the degree of complexity of the firm's environmental international diversification, which matters in developing proactive environmental strategies (Aguilera-Caracuel et al., 2012).

As to contracted assemblers, the customers seek those that are closer to their environmental management philosophy. For example, Corporation 5 attends to customers with higher environmental management maturity, whereas the customers of Corporation 8 tend to be closer to the preventive maturity level.

Therefore, for environmental managers and businessmen interested in business in the hightechnology sector in Brazil, the following observations are offered:

- Collaboration between companies tends to bring corporations that are at the same environmental maturity level closer together;

- If a manager is interested in conducting business with environmentally advanced multinational corporations, she/he first must improve his/her environmental management;

- The diagnosis of organisational environmental maturity tends to be important for organisations that want to be part of environmentally friendly supply chains since there is a trend of global chains seeking a minimum alignment between the members of chain with respect to environmental concerns;

- The perspective of using the productive process stage (input-transformation-output) might guide companies in finding adoption of environmental practices in order to gradually advance in the maturity of organisational environmental management;
- Most of the studied cases have environmental management concerned with environmental legislation and eco-efficiency;

- The New Brazilian Policy on Solid Waste may induce the corporations to increase their environmental management levels in the future.

\section{References}

Aguilera-Caracuel, J., Hurtado-Torres, N. E., \& Aragón-Correa, J. A. (2012). Does international experience help firms to be green? A knowledge-based view of how international experience and organisational learning influence proactive environmental strategies. International Business Review, 21(5), 847-861. http://dx.doi.org/10.1016/j.ibusrev.2011.09.009.

Azzone, G., \& Bertelè, U. (1994). Exploiting green strategies for competitive advantage. Long Range Planning, 27(6), 69-81. http://dx.doi.org/10.1016/0024-6301(94)90165-1.

Barbieri, J. C. (2004). Gestão ambiental empresarial. São Paulo: Saraiva.

Berry, M. A., \& Rondinelli, D. A. (1998). Proactive corporate environmental management: a new industrial revolution. The Academy of Management Executive, 12(2), 38-50.

Corazza, R. 1. (2003). Gestão ambiental e mudanças da estrutura organizacional. Revista de Administração de Empresas, 2(2), 1-23.

Donaire, D. (1994). Considerações sobre a influência da variável ambiental na empresa. Revista de Administração de Empresas, 34(2), 68-77. http://dx.doi.org/10.1590/ S0034-75901994000200008.

Epstein, M. J., \& Roy, M. (2007). Implementing a corporate environmental strategy: establishing coordination and control within multinational companies. Business Strategy and the Environment, 6(6), 389-403. http://dx.doi. $\operatorname{org} / 10.1002 /$ bse. 545 .

Garrod, B., \& Chadwick, P. (1996). Environmental management and business strategy: towards a new strategic paradigm. Futures, 28(1), 37-50. http://dx.doi.org/10.1016/00163287(95)00076-3.

González-Benito, J., \& González-Benito, 0. (2006). A review of determinant factors of environmental proactivity. Business Strategy and the Environment, 15(2), 87-102. http://dx.doi. org/10.1002/bse.450.

Huang, Y. C., Wong, Y. J., \& Yang, M. L. (2014). Proactive environmental management and performance by a controlling family. Management Research Review, 37(3), 210-240. http://dx.doi.org/10.1108/MRR-09-2012-0196.

Hunt, C. B., \& Auster, E. R. (1990). Proactive environmental management: avoiding the toxic trap. Sloan Management Review, 31(2), 7-18.

Jabbour, A. B. L. S. (2014). Evidências da relação entre a evolução da gestão ambiental ea adoção de práticas de green supply chain management no setor eletroeletrônico brasileiro. Revista de Administração, 49(3), 606-616. http:// dx.doi.org/10.5700/rausp 1171 .

Jabbour, A. B. L. S., Jabbour, C. J. C., Sarkis, J., \& Govindan, K. (2014). Brazil's new national policy an solid waste: challenges and opportunities. Clean Technologies and Environmental Policy, 16(1), 7-9. http://dx.doi.org/10.1007/ s10098-013-0600-z. 
Jabbour, C. J. C. (2010). Non-linear pathways of corporate environmental management: a survey of ISO 14001- certified companies in Brazil. Journal of Cleaner Production, 18(12), 1222-1225. http://dx.doi.org/10.1016/j.jclepro.2010.03.012.

Jabbour, C. J. C., \& Santos, F. C. A. (2006). The evolution of environmental management within organizations: toward a common taxonomy. Environmental Quality Management, 16(2), 43-59. http://dx.doi.org/10.1002/tqem.20120.

Jabbour, C. J. C., Santos, F. C. A., \& Jabbour, A. B. L. S. (2009a). A importância dos fatores humanos no desenvolvimento de produtos com elevado desempenho ambiental: estudo de casos. Revista de Administração Mackenzie, 10(4), 32-56.

Jabbour, C. J. C., Santos, F. C. A., \& Nagano, M. S. (2009b). Análise do relacionamento entre estágios evolutivos da gestão ambiental e dimensões de recursos humanos: Estado da arte e survey em empresas brasileiras. Revista de Administração da USP, 44(4), 342-364.

Jabbour, C. J. C., Silva, E. M., Paiva, E. L., \& Santos, F. C. A. (2012). Environmental management in Brazil: is it a completely competitive priority? Journal of Cleaner Production, 21(1), 11-22. http://dx.doi.org/10.1016/j. jclepro.2011.09.003.

Jabbour, C. J. C., Teixeira, A. A., \& Jabbour, A. B. L. S. (2013). Treinamento ambiental em organizações com certificação ISO 14001: estudo de múltiplos casos e identificação de co-evolução com a gestão ambiental. Produção, 23, 80-94.

Kolk, A., \& Mauser, A. (2002). The evolution of environmental management: from stage models to performance evaluation. Business Strategy and the Environment, 11(1), 14-31. http://dx.doi.org/10.1002/bse.316.

Liu, X., Liu, B., Shishime, T., Yu, Q., Bi, J., \& Fujitsuka, T. (2010). An empirical study on the driving mechanism of proactive corporate environmental management in China. Journal of Environmental Management, 91(8), 1707-1717. http:// dx.doi.org/10.1016/j.jenvman.2010.03.011. PMid:20399552.

Maimon, D. (1994). Eco-estratégia nas empresas brasileiras: realidade ou discurso? Revista de Administração de Empresas, 34(4), 119-130. http://dx.doi.org/10.1590/ S0034-75901994000400013.

Muduli, K., Govindan, K., Barve, A., \& Geng, Y. (2013). Barriers to green supply chain management in Indian mining industries: a graph theoretic approach. Journal of Cleaner Production, 47, 335-344. http://dx.doi.org/10.1016/j. jclepro.2012.10.030.

Nascimento, L. F., Lemos, A. D. C., \& Mello, M. C. A. (2008). Gestão socioambiental estratégica. São Paulo: Bookman.

Ormazabal, M., \& Sarriegi, J. M. (2014). Environmental management evolution: empirical evidence from Spain and ltaly. Business Strategy and the Environment, 23(2), 73-88. http://dx.doi.org/10.1002/bse.1761.

Ormazabal, M., Sarriegi, J. M., Barkemeyer, R., Viles, E., \& McAnulla, F. (2013). Evolutionary pathways of environmental management in UK companies. Corporate Social Responsibility and Environmental Management. No prelo.
Park, J., \& Ahn, Y. (2012). Strategic environmental management of Korean construction industry in the context of typology models. Journal of Cleaner Production, 13(1), 158-166. http://dx.doi.org/10.1016/j.jclepro.2011.10.032.

Post, J. E., \& Altman, B. W. (1994). Managing the environmental change process: barriers and opportunities. Journal of Organizational Change Management, 7(4), 64-81. http:// dx.doi.org/10.1108/09534819410061388.

Rohrich, S. S., \& Cunha, J. C. D. (2004). A proposição de uma taxonomia para análise da gestão ambiental no Brasil. Revista de Administração Contemporânea, 8(4), 81-97.

Sanches, C. S. (2000). Gestão ambiental proativa. Revista de Administração de Empresas, 40(1), 76-87. http://dx.doi. org/10.1590/S0034-75902000000100009.

Sarkis, J. (1998). Evaluating environmentally conscious business practices. European Journal of Operational Research, 107(1), 159-174. http://dx.doi.org/10.1016/S0377-2217(97)00160-4.

Sarkis, J., \& Rasheed, A. (1995). Greening the manufacturing function. Business Horizons, 38(5), 17-27. http://dx.doi. org/10.1016/0007-6813(95)90032-2.

Sehnem, S., \& Rossetto, A. M. (2014). Estratégia ambiental e desempenho econômico e ambiental: um modelo de análise para o setor de frigoríficos. Gestão \& Produção, 21(4), 745-759. http://dx.doi.org/10.1590/0104-530X834-11.

Seiffert, M. E. B. (2009). Gestão ambiental: instrumentos, esferas de ação e educação ambiental. São Paulo: Atlas.

Stevens, P. A., Batty, W. J., Longhurst, P. J., \& Drew, G. H. (2012). A critical review of classification of organisations in relation to the voluntary implementation of environmental management systems. Journal of Environmental Management, 113, 206-212. http://dx.doi.org/10.1016/j. jenvman.2012.08.037. PMid:23037315.

Vastag, G., Kerekes, S., \& Rondinelli, D. A. (1996). Evaluation of corporate environmental management approaches: A framework and application. International Journal of Production Economics, 43(2), 193-211. http://dx.doi. org/10.1016/0925-5273(96)00040-0.

Widmer, R., Oswald-Krapf, H., Sinha-Khetriwal, D., Schnellmann, M., \& Böni, H. (2005). Global perspectives on e-waste. Environmental Impact Assessment Review, 2(5), 436-458. http://dx.doi.org/10.1016/j.eiar.2005.04.001.

Zhu, Q., Sarkis, J., \& Lai, K. H. (2012). Green supply chain management innovation diffusion and its relationship to organizational improvement: An ecological modernization perspective. Journal of Engineering and Technology Management, 29(1), 168-185. http://dx.doi.org/10.1016/j. jengtecman.2011.09.012.

\section{Acknowledgements}

This research received support from the FAPESP - The Sao Paulo State Research Foundation (\#2010/11553-2; \#2011/11219-8). 